\title{
Departementschefsrollen sprængt i stumper og stykker
}

Peter Loft og Jørgen Rosted, 2016

Hvem har ansvaret? Revner og sprækker i det danske embedssystem

Gyldendal

278 sider, 299,95 kr.

Anmeldt af Tim Knudsen

Problemstillingen

Om tiden er løbet fra den særlige danske udformning af ministerialsystemet med kun en politisk udpeget minister - dog tilsat en eller to særlige rådgivere - og en mængde karriereembedsfolk i hvert ministerium har været diskuteret længe. Lidt forenklet har der været to synspunkter. Det ene er, at nok har der været en del skandalesager, men det skyldes enkeltpersoners fejl. Systemet er godt nok i sig selv. Der kan dog godt foretages nogle småjusteringer for at følge med tiden. Det andet synspunkt er, at der er ganske mange uheldige sager, hvor love overtrædes, hvor der misinformeres, og hvor embedsfolk tilsidesætter faglige standarder af politiske grunde. Det er til skade for retssikkerheden, effektiviteten og befolkningens tillid til systemet. Departementerne har udviklet sig til politikfabrikker og deres embedsmænd til politikmagere. Det er et systemproblem, fordi det er blevet svært for embedsfolk at skræve over både at producere politik til ministerens bedste og samtidig tilgodese de klassiske krav, der knytter sig til begrebet god forvaltningsskik.

To erfarne topembedsmænd

To tidligere topembedsmænd med erfaringer fra tilsammen 27 år som departementschefer slutter sig i denne bog til sidstnævnte synspunkt. Så vidt kommer de ikke med noget 
nyt. Lignende diagnoser findes for eksempel i bogen Ansvaret der forsvandt af Pernille Boye Koch og Tim Knudsen samt i bøger af Jesper Tynell og Christian Nissen samt i akademiske arbejder af Birgitte Poulsen. Forfatternes praktiske erfaring giver imidlertid deres ord vægt, når de skriver, at især departementschefernes rolle er blevet overbelastet med til dels modsatrettede krav.

Departementscheferne er på den ene side ministrenes vigtigste rådgivere og hjælpere. Ministrenes succes er således blevet et væsentligt succeskriterium for en departementschef. Det forplanter sig ned i ministeriernes organisation og kultur, så der er en større risiko end tidligere for, at der opstår 'møgsager' på kanten af loven, sandheden og fagligheden. Forfatterne peger samtidigt på, at mens departementscheferne er underlagt et ofte modsatrettet krav om partipolitisk neutralitet, som skal gøre det muligt for dem at betjene en ny regering, så er de yderligere underlagt nogle grænser for, hvor meget politisk hjælp de kan give ministrene. Det ytrer sig for eksempel ved, at de har vanskeligt ved at gribe ind, når der er interne konflikter i regeringen eller i konflikter mellem ministeren og dennes partibagland. Eksempelvis kunne det være lettere for en politisk hjælper end en karriereembedsmand at hjælpe i sagen om den forsmædeligt kulsejlede betalingsring ved at tale med socialdemokratiske omegnsborgmestre. De to forfattere antyder tillige en passant, at en departementschef med en minister, der også sidder i de centrale regeringsudvalg, også skal råde i sager, som departementschefen kan have lige så lidt begreb om både fagligt og politisk som ministeren. Et eksempel, som er hentet fra en departementschefskollega, er, at Socialministeriets departementschef har rådet ministeren om resurser i Arktis.

Forfatterne kunne have nævnt, at Danmark det sidste årti er sejlet økonomisk agterud ift. nabolandene. Spørgsmålet er her, om det blandt andet skyldes manglende kreativitet $\mathrm{i}$ departementerne. Endelig kunne forfatterne også godt have pointeret lidt mere, at det er demokratisk betænkeligt, når kun en i hvert ministerium har et parlamentarisk ansvar. Med et system af viceministre bredes det parlamentariske ansvar ud. Derimod giver forfatterne eksempler på møgsager, som de formoder, kunne have være afværget, hvis man havde et mere smidigt korps af politiske hjælpere udpeget på både politisk og fagligt grundlag, som man har det i vore nabolande. 
De to veje at gå

De peger på to mulige veje at gå. Begge veje vil (gen)skabe et større skel mellem det politiske og det faglige. Enten kan man tilnærme sig en svensk model med en række politisk udnævnte topembedsmænd i departementerne. I øvrigt bevares en række karriereembedsfolk i departementerne. Modellen indebærer, at ministeransvaret for sagsbehandlingen $\mathrm{i}$ styrelser og direktorater forsvinder. Ansvaret for 'møgsager vil ligge $\mathrm{i}$ styrelserne. En ulempe ved modellen kan være, at det kan blive sværere at inddrage styrelsernes erfaringer i det lovforberedende arbejde. I øvrigt var det det modsatte, der foregik i Skatteministeriet, da Peter Loft var departementschef der. Her gennemførte man en såkaldt enhedsorganisation, som man efter Lofts afgang opgav til fordel for en klar deling mellem departement og styrelse.

En anden model er, at der udnævnes viceministre og en hel stab af politiske rådgivere i hvert departement. I mange stater har man netop sådanne 'kabinetter' eller sekretariater. Ved siden af har man almindelige partineutrale embedsfolk. I toppen for disse sidder en departementschef. Ministeren får både politisk og faglig rådgivning, men rådgivningen opdeles mellem politiske hjælpere og karriereembedsmænd. Politisk vigtige sager får så ofte en tresidet behandling i samtaler mellem minister, toprådgiveren og departementschefen. Denne model er formentlig nemmere at udvikle i forlængelse af det eksisterende danske system.

De nævnte forslag er meget løst skitserede (det vides ikke, om det skyldes uenigheder mellem de to forfattere, men det kunne være en medvirkende årsag). Eksempelvis nævnes muligheden for at indføre viceministre kun i forbifarten. Flere overvejelser om rekrutteringen af politiske hjælpere til ministrene, og om ansvarssystemet kunne let være gjort. Efter min opfattelse bør en rekruttering af politiske hjælpere ligge hos den enkelte minister, hvis ikke man skal risikere, at de bliver opfattet som regeringsledelsens spioner i ministeriet. Forfatterne kunne også med fordel have ofret Folketingets kontrolfunktion med den udøvende magt lidt mere opmærksomhed. En kvalitet ved netop viceministermodellen er som nævnt, at en viceminister vil have parlamentarisk ansvar. Folketinget vil med andre ord direkte kunne stille flere end en minister til ansvar i hvert ministerium. 
Forandring kommer under alle omstændigheder

Forfatterne skal have stor ros for, at de har skrevet denne debatbog. De har ganske ret $\mathrm{i}$, at systemet som altid vil forandre sig langsomt, selv hvis man ikke træffer bevidste valg. Spørgsmålet er alene, om man vil foretage et bevidst og gennemtænkt valg, som forklares for alle. Eller om man hellere vil lade udviklingen foregå inkrementelt. Allerede for tretten år siden forudsagde Svend Auken, at systemet med særlige rådgivere gradvist vil udvikle sig til politiske kabinetter. Jeg tror, han havde ret. Problemet ved ikke at træffe klare forvaltningspolitiske valg er, at en sådan udvikling så vil give rolleproblemer og konflikter. De to forfattere har desuden den frygt, at der vil komme en snigende partipolitisering af departementscheferne ind ad bagdøren. I forvejen skiftes departementschefer i nutiden langt hurtigere ud end i fortiden. Det kunne ende med, at nye regeringer skifter så godt som hele toppen ud, når de træder til.

Departementscheferne burde efter forfatternes mening have en klar stillingsbeskrivelse, så de kunne koncentrere sig om at sikre, at ministeriernes organisation fungerer effektivt, og at der arbejdes inden for rammerne af lovlighed, sandhed og faglighed. Det er jo egentligt også grotesk, at man tre gange har skrevet fyldige betænkninger om de særlige rådgiveres rolle (betænkningerne 1354, 1443 og 1537), men officielt aldrig har defineret departementschefernes rolle.

De foreslår også, at en departementschef ikke alene skal drøfte sagen med Statsministeriets departementschef, hvis ministeren presser embedsfolkene til ulovligheder. Departementschefen skal også sige fra skriftligt og sende meddelelsen om sin advarsel videre til Statsministeriet, så det efterfølgende står helt klart, hvad de har advaret ministeren mod. Det kan forebygge de møgsager, hvor minister og embedsmænd efterfølgende giver stik modsatte forklaringer, som vi eksempelvis har set det i statsløsesagen.

\section{Det beståendes inerti}

Det er aldrig sket før, at embedsfolk så udførligt redegør for deres surt erhvervede erfaringer. Langt de fleste af de to forfatteres forgængere tog helst deres erfaringer med i graven. Resultatet er, at det vigtige offentlige anliggende, som embedsmandsrollen er, henligger i halvmørke. Den nye bog indeholder mange gode og oplysende argumenter 
og eksempler. Naturligvis med departementscheferne i centrum, man mærker, at de to er optaget af at sikre departementscheferne mod at komme galt af sted. Sådan må det nok være, når man betænker, at Peter Lofts mange år i det i øvrigt problembefængte Skatteministerium fik en brat afslutning med det, der blev kaldt Helle Thornings skattesag.

Stærke kræfter forsvarer det bestående. Statsministeriets departementschef Christian Kettel Thomsen har allerede taget til genmæle mod de to forfattere. Departementscheferne er blevet bedre kvalificerede, siden forfatterne blev departementschefer, hævder Thomsen. Men problemet er ifølge bogen ikke bare kvalifikationerne, det er også tiden, arbejdspresset og de mange til dels modsatrettede krav. Eftersom Thomsen i praksis har været hovedmand bag udnævnelsen af de nuværende topembedsmænd, er det kun, at Thomsen forsvarer det bestående. En anden indvending vil være, at de to forfattere kun har erfaringer fra få ministerier, men at de ikke kan overføres på andre ministerier. Det er jeg nu ikke så sikker på. Men det ville unægteligt være lettere at gøre sig den slags overvejelser, hvis andre tidligere topembedsmænd redegjorde for deres erfaringer. De to forfattere er dog ikke ganske alene. Tidligere topembedsfolk som for eksempel Michael Christiansen, Anders Troldborg og Christian Nissen har hver på deres måde og i kortere form også tilkendegivet, at det danske system kunne være ved at nærme sig vejs ende. De og andre tidligere topembedsmænd måtte gerne fortsætte med at delagtigtiggøre os i deres erfaringer. 